\title{
Modellvegyületektől a gyakorlati fontosságú származékokig: barangolásaim a szervetlen és szerves kémia határterületein
}

\author{
KOLLÁR László ${ }^{\mathrm{a}, \mathrm{b} *}$ \\ aPécsi Tudományegyetem TTK, Kémiai Intézet, Szervetlen Kémiai Tanszék és \\ MTA-PTE Szelektiv Kémiai Szintézisek Kutatócsoport, 7624 Pécs, Ifjúság u. 6 \\ ${ }^{b}$ Szentágothai János Kutatóközpont, Zöldkémiai Kutatócsoport, 7624 Pécs, Ifjúság u. 20.
}

Tisztelt Elnök Úr, Osztályelnök Úr! Kedves Kollégáim! Hölgyeim és Uraim!

Az első szó természetesen a köszöneté. Öszinte hálával tartozom mindazoknak, akik több fordulón keresztül nevüket adták ahhoz, hogy támogatásukkal az Osztály jelöltjei között szerepelhessek.

A homogén katalízis területén dolgozó kutatóként szeretném hangsúlyozni, hogy a szervetlen és a szerves kémia határterületén mozogva mind a hagyományosan szervetlen kémia területéhez sorolt koordinációs kémiában, mind a szerves szintetikus kémiában némi jártasságra van szükség. A különböző átmenetifém-komplexeket - gyakran mint eszközöket - alkalmazzuk egyszerübb modellvegyületek átalakulásának vizsgálatára vagy éppen nagy bonyolultságú, biológiai fontosságú alapvázak új funkciós csoportjának kiépítésére (1. Ábra). Kutatásaim egy másik vonulata is felvázolható: bár munkám egyik sarokeleme az egyszerü, néhány atomos kismolekulák aktiválása, különböző bonyolultságú struktúrákba történő beépítése, megjelennek a nagy kemo-, sztereo- és esetenként enantioszelektivitású reakciókban felépített gyakorlati fontosságú vegyületek (szteroidok, terpének, kavitandok) is.

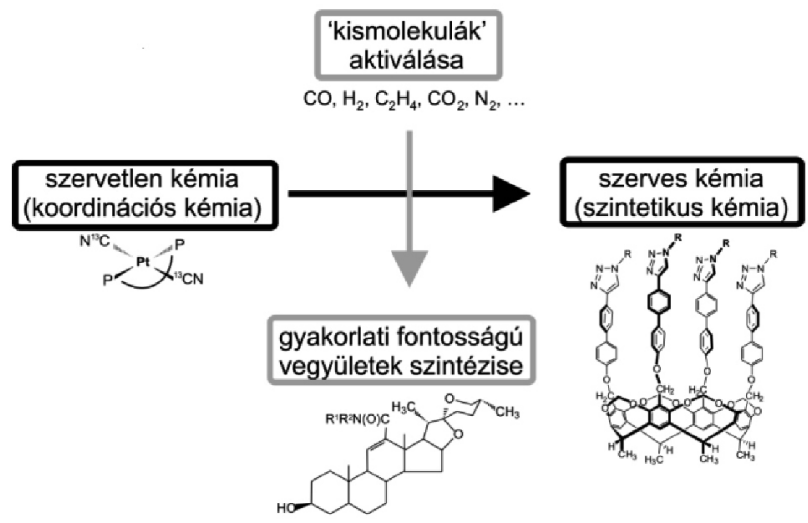

1. Ábra A homogén katalízis mint határterületi kutatás

A fenti átalakítások döntően homogén katalitikus reakciókban történnek. Ez azt jelenti, hogy az átmenetifémek nem szilárd katalizátorként (mint pl. autóinkban) szerepelnek ezen reakciókban, hanem oldott állapotban levő komplexek formájában. Ezt úgy érjük el, hogy a fématomok vagy fémionok ligandumokkal körülvéve fejtik ki hatásukat. Míg a heterogén fém-katalizátorok esetében a katalitikus aktivitás a fém felületének kitüntetett pontjaihoz (aktív helyeihez) köthető, addig a homogén katalizátorok esetében

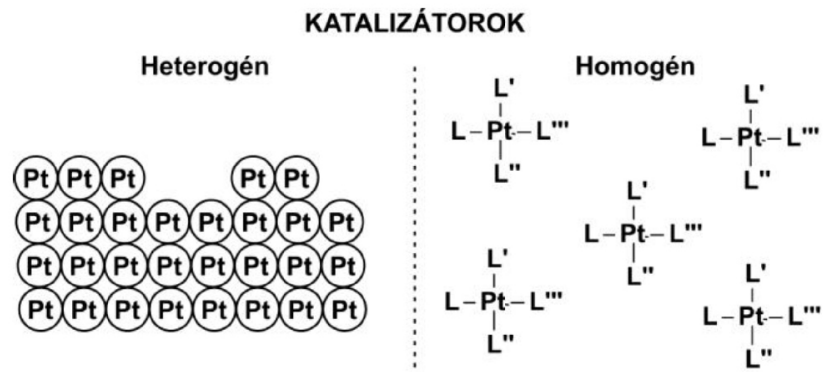

- legalábbis potenciálisan - minden fématom katalitikusan aktív centrumként jelentkezik (2. Ábra).

2. Ábra A heterogén és homogén katalizátorok összehasonlítása

Az ilyen, immár egyszerű szerves ligandumot is tartalmazó első átmenetifém-komplex felfedezése Zeise nevéhez füződik. ${ }^{1}$ Amint a Poggendorff's Ann. Physik und Chemie, majd a később megjelent Liebigs Annalen der Chemie folyóiratból - ha nem is egyszerüen - megállapítható, a kiváló kísérletező dán gyógyszerész kálium-[hexakloro-platinát(IV)] komplex tisztítását, átkristályosítását végezte etanolból. Az etanol kétféle szerepben is megjelenik e reakcióban: egyrészt redukálószerként a platina (IV)-et platina(II)-vé alakítja, másrészt vízvesztéssel etilént szolgáltat, amely a $\mathrm{Pt}(\mathrm{II})$ koordinációs szférájában megjelenik termékként 'éghető platinasót' (sal kalico platinicus imflammibilis) adva (3. Ábra). Az etilén a koordinációs szférában aktivált formában található: a szén-szén kötés megnyúlik, a hidrogén-atomok a fémtől enyhén kifelé hajlanak. A szénatom a sík ( $\mathrm{sp}^{2}$ hibridállapottal jellemezhető) geometriából a tetraéderes ( $\mathrm{sp}^{3}$ hibridállapot) felé mozdul el. Nem véletlen, hogy ez a komplex hihetetlenül részletesen vizsgált. Minden homogénkatalitikus alkén átalakítás (pl. hidrogénezés, hidroformilezés) kitünő modellje, az alkének átmenetifémekkel történő aktiválásának tankönyvi példája. $^{2}$

\footnotetext{
* Kollár László. Tel.: 72-503600/24153; fax: 72-503518; e-mail: kollar@gamma.ttk.pte.hu; (A 2016. szeptember 20-án elhangzott akadémiai székfoglaló szerkesztett változata.)
} 


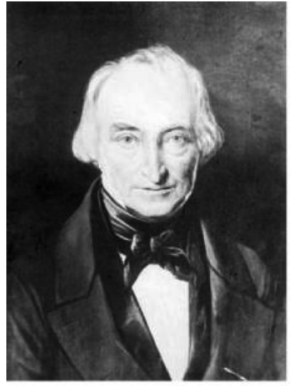

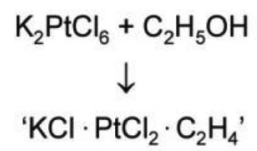

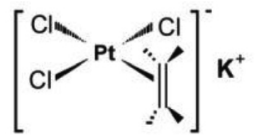

'sal kalico-platinicus inflammibilis'

W. C. Zeise

(1789-1847)

3. Ábra. Az átmenetifém-organikus kémia egyik alapvegyülete, a Zeise-só

A következő percekben kutatómunkám legutóbbi eredményeiről, koordinációs kémiai és szintetikus kémiai érdekességeiről egyaránt szeretnék beszámolni.

A most bemutatásra kerülő platina(II) komplexek koordinációs kémiai vizsgálatai valójában még veszprémi kutatómunkám egyik kulcskomplexéhez kötődnek. Platina- bdpp (bdpp=2,4-bisz(difenilfoszfino)-pentán) komplexekkel végzett katalitikus és koordinációs kémiai vizsgálataink során - itt nem részletezendő nagy szelektivitású ligandum-csere reakcióban sikerült izolálnunk a $\mathrm{PtI}(\mathrm{SnCl} 3)(\mathrm{bdpp})$ komplexet. $^{3}$ (Bár oldatok NMR vizsgálata alapján a Pt-Sn kötés jelenléte ismert volt, első ízben sikerült ezt krisztallográfiás úton is igazolnunk.) A várakozásnak megfelelően a komplex síknégyzetes szerkezetü, mely világosan látszik a 4. Ábrán, ahol a komplex 'felülnézeti' szerkezetét mutatom be.

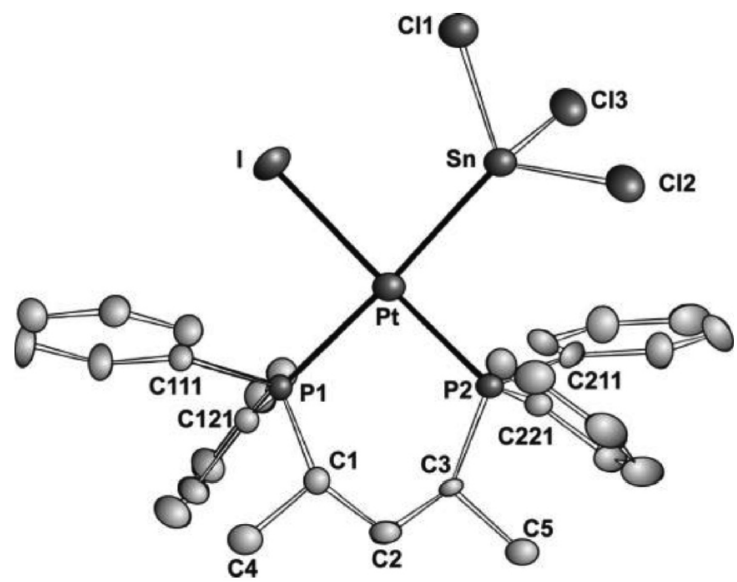

4. Ábra. $\operatorname{A~PtI(}\left(\mathrm{SnCl}_{3}\right)(\mathrm{bdpp})$ komplex röntgenkrisztallográfiával meghatározott szerkezete ('felülnézet')

A komplex 'oldalnézeti' képe több meglepetést tartogat: A Pt-bdpp hattagú kelátgyürü több konformerét sikerült detektálnunk. A legnagyobb stabilitású, a ligandum metilcsoportjait ekvatoriális helyzetben tartalmazó $\delta$-skew konformer (5. Ábra) mellett megjelennek az axiális-ekvatoriális metilcsoport elrendeződést mutató konformerek is. ${ }^{4}$

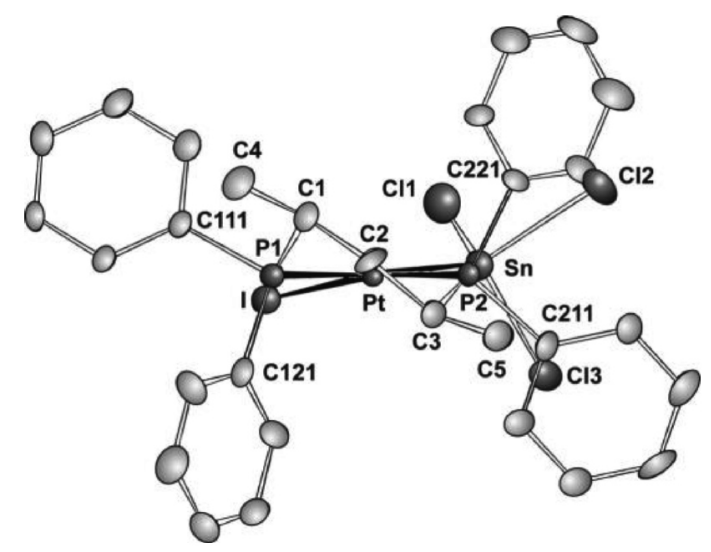

5. Ábra A PtI(SnCl3)(bdpp) komplex egyik kelát-konformerének röntgenkrisztallográfiával meghatározott szerkezete ('oldalnézet')

A fenti difoszfin ligandummal izolált, egykristály röntgenszerkezeti vizsgálatokból kiderült, hogy többféle ligandum-környezetben - így a platina-fenil komplexek esetében is ${ }^{5}$ - megtalálható a platina-központi fématomot, a két foszforatomot és a három szénatomot tartalmazó hattagú kelátgyürü szék konformere is (6. Ábra).

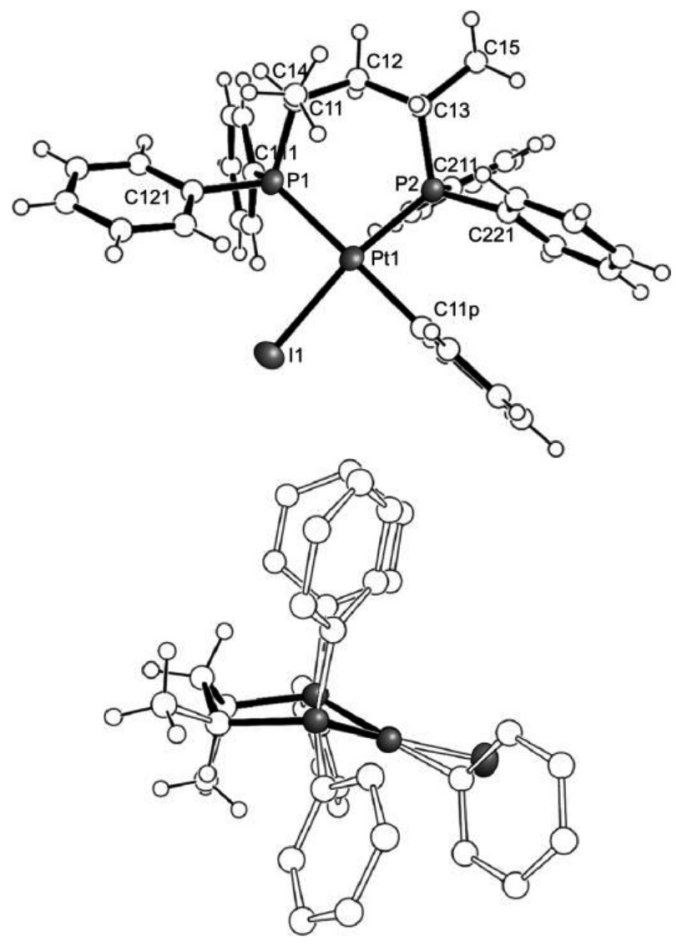

6. Ábra. A PtI(Ph)(bdpp) komplex röntgenkrisztallográfiával meghatározott szerkezete ('felülnézet' (fent), 'oldalnézet' (lent))

A platinakomplexekkel történt NMR (HP NMR), IR és röntgenkrisztallográfiás vizsgálatok azért kerültek érdeklődésünk homlokterébe, mert a platina-bdpp-ón(II)klorid katalizátorrendszerek nemcsak aktív katalizátornak bizonyultak, hanem a legszélesebb körben vizsgált sztirol modellvegyülettel kitünő enantioszelektivitást is eredményeztek ${ }^{6,7} \mathrm{~A}$ 
sztirol-származékok enantioszelektív hidroformilezése nemcsak az elméleti összefüggések feltárása miatt érdekes, hanem azért is, mert az elágazó királis formil-regioizomer termék, a 2-fenil-propanal az általánosan használt 'nem-szteroidális' gyulladásgátló hatású gyógyszer, az ibuprofen analóg intermedierének tekinthető. ${ }^{8,9}$ Ily módon a sztirol-származékok aszimmetrikus hidroformilezése megoldást jelenthet ezen származékok enantiomerikusan tiszta formában történő előállítására. (7. Ábra).

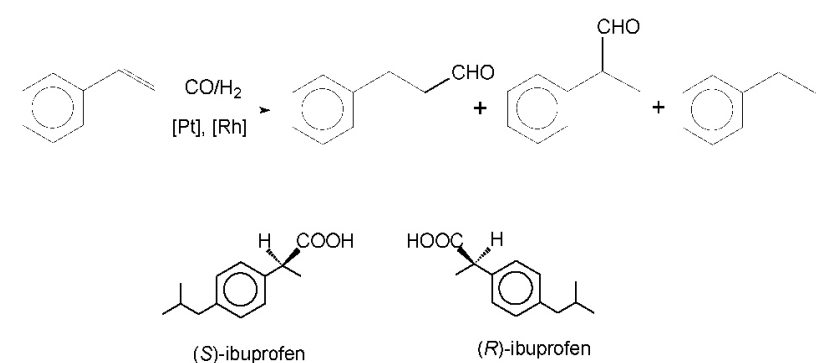

7. Ábra Sztirol homogénkatalitikus hidroformilezése

A fenti rendszerekkel végzett reakciómechanizmusvizsgálatok közül csupán egyetlen részletet emelnék ki. HP NMR vizsgálatokkal igazolni tudtuk, hogy az ón(II)-klorid jelenléte nélkülözhetetlen a katalitikus aktivitás eléréséhez. Platina-metil modellvegyület HP NMR vizsgálata során igazoltuk, hogy a szén-monoxid koordinációja és Pt-Me kötésbe történő beékelődése ugyan ón(II)-klorid-mentes rendszerben is lejátszódik, de az acetil komplexből nem nyerhető az acetaldehid. A vizsgálatok során komplex kationokat azonosítottunk, amelyek ellenionja a klorid ion (8. Ábra, felső reakciósor).

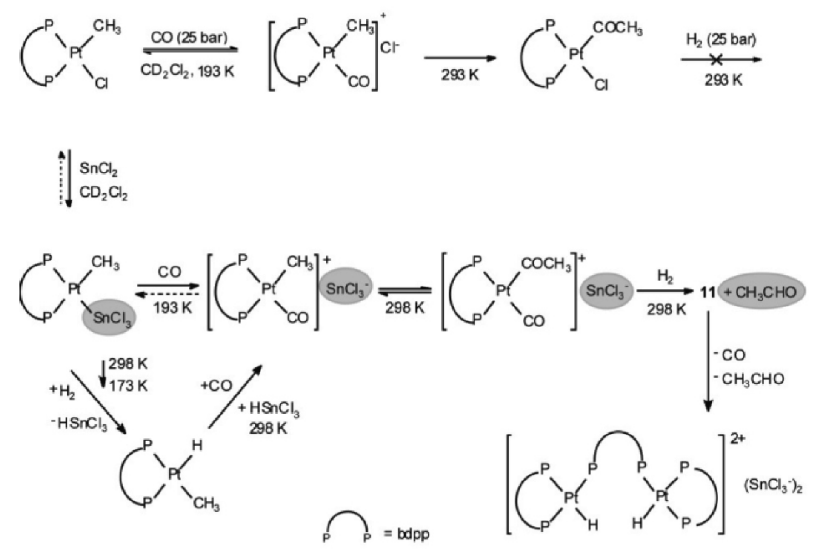

8. Ábra Az ón(II)-klorid szerepének vizsgálata HP NMR segítségével

Ezzel szemben ón-klorid jelenlétében triklorosztannátellenion szerepel a platina-karbonil komplexek ellenionjaként. Ez az ón(II)-klorid beékelődésével nyert Pt-SnCl3 komplexből, a jó távozó triklorosztannáto ligandum disszociációjával keletkezett. Helyére szénmonoxid lép be, melynek Pt-Me kötésbe történő beékelődését egy újabb szén-monoxid molekula belépése követi. Ily módon terminális karbonil ligandumot tartalmazó acetil-karbonil komplexet kaptunk, melynek hidrogénnel történő reakciója acetaldehidet szolgáltat (8. Ábra, alsó reakciósor). ${ }^{10}$
A sztirollal és annak orto- és para-szubsztituált származékaival (9. Ábra) Pt-bdpp-ón(II)-klorid katalizátorrendszer jelenlétében végzett enantioszelektív hidroformilezési reakciók egy alapvetően új jelenségre irányították a figyelmünket. ${ }^{11,12} \mathrm{~A}$ katalitikusan aktív rendszer teljes müködési tartományában végzett vizsgálatokból kiderült, hogy a $(2 S, 4 S)$-bdpp-t tartalmazó katalizátorral alacsony hőmérsékleten az $(S)-2$ fenil-propanal, magasabb hömérsékleten pedig annak $(R)$-enantiomerje képződik nagyobb mennyiségben (10. Ábra).

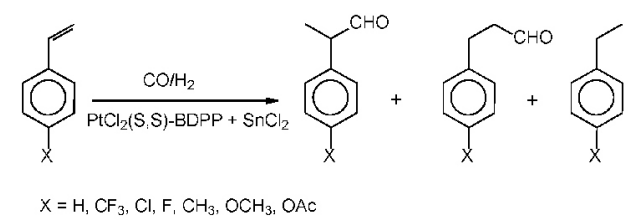

9. Ábra para-Szubsztituált sztirolok platina-katalizált hidroformilezése

Bár kézenfekvőnek tünt az az elképzelés, hogy a kedvezményezett enantiomerek képződését a két konformer jelenlétével magyarázzuk, Casey és munkatársai, ${ }^{13}$ valamint kutatócsoportunk eredményei arra világítottak rá, hogy egyértelmüen kinetikus hatásról van szó.

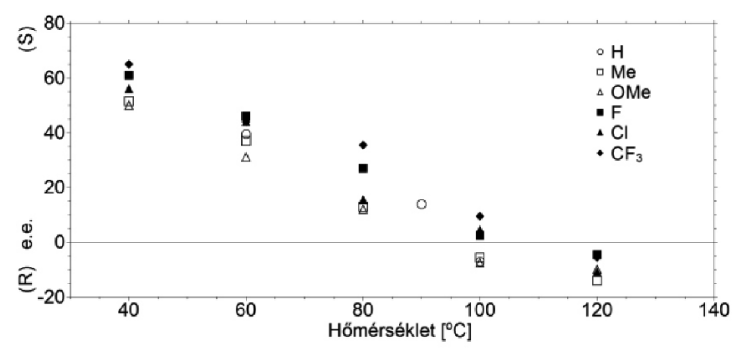

10. Ábra Az enantioszelektivitás változása a hőmérséklet függvényében para-szubsztituált sztirolok platina-bdpp-ón(II)-klorid katalizátorrendszerrel történő hidroformilezése során.

A Pt-alkil intermedier képződése irreverzibilis alacsony hőmérsékleten, azaz a $\beta$-hidrid elimináció nem kedvezményezett (11. Ábra, felső sor). A beékelődés reverzibilis magas hőmérsékleten, azaz szabad sztirolt eredményez, amely a másik enantiooldallal koordinálódva és a Pt-H kötésbe ékelődve a másik enantiomerhez vezető platina-alkil komplexet eredményezi (11. Ábra, alsó sor).

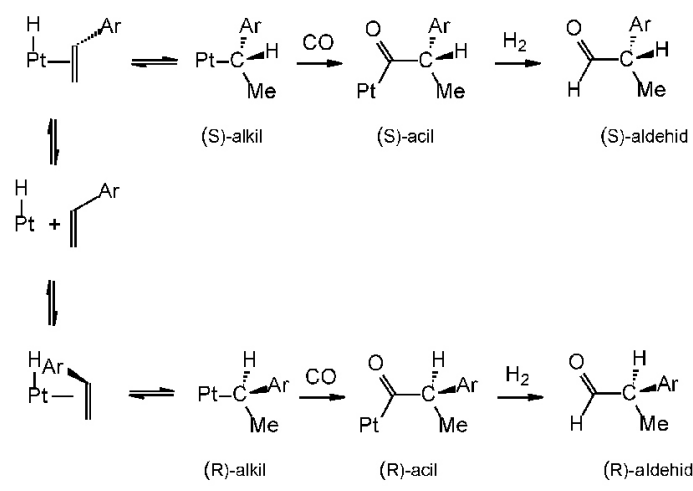

11. Ábra. Az alkén Pt-H kötésbe történő beékelődése

A különböző para-szubsztituált sztirolokkal végzett hidroformilezési reakciók eredményei a fenti mechanizmussal a következőképpen magyarázhatók. 
Az elektronküldő szubsztituensek (pl. metil, metoxi) növelik a Pt-alkil kötés képződés reverzibilitását, ily módon csökken az enantioszelektivitás-váltás hőmérséklete $\left(\mathrm{T}_{\text {rev }}\right)$ ). Ezek a szubsztituensek növelik az (S)-alkil intermedier Pt-szén kötésének elektronsűrüségét. A $\beta$-hidrid elimináció kedvezményezett a szén-monoxid beékelődéshez képest. Sztirol 'újraképződése' játszódik le, melynek Pt-H kötésbe történő beékelődése az $(R)$-enantiomert eredményezi. Az elektron-akceptor szubsztituensek (pl. trifluormetil) csökkentik a Pt-alkil kötés képződésének reverzibilitását, ily módon nő az enantioszelektivitás-váltás hőmérséklete (Trev).

Szakmai fórumokon gyakran felvetődött a kérdés: valóban csak a platina-kloro komplexek szerepelhetnek katalizátorprekurzorként ón-halogenidek jelenlétében? Különböző platina(II)-aril és -alkil komplexeket bór-trifluorid és trisz(pentafluorfenil)borán ('BARF') Lewis-savak jelenlétében reagáltatva ugyancsak komplex kationokhoz jutunk. A borán-származékok a semleges diaril (vagy dialkil) komplexek egyik aril (vagy alkil) csoportjával borátokat képeznek, ily módon üres koordinációs helyeket létesítenek a síknégyzetes komplexben, ahova különböző típusú ligandumok (szén-monoxid, foszfinok, alkének) koordinálódhatnak (12. Ábra). A borán-származékok kitünő homogénkatalitikus hidroformilező aktivitással rendelkeznek. Sztirol hidroformilezése során az ón-klorid kokatalizátort tartalmazó rendszerekkel összemérhető aktivitást, valamint kemo-, regioés enantioszelektivitást kaptunk.

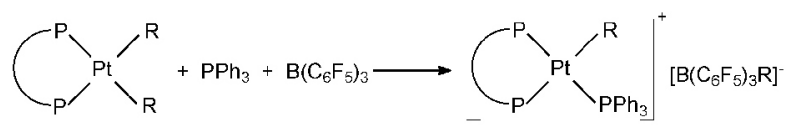

$\mathrm{R}=\mathrm{Me}, \mathrm{Ph}, 2-\mathrm{Thioph}$

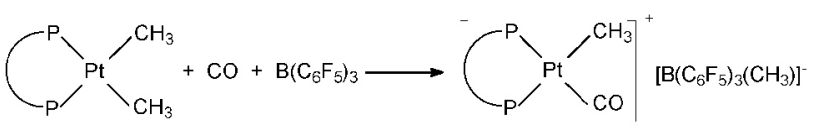

12. Ábra Platina-alkil/aril komplexek reakciói $\mathrm{B}\left(\mathrm{C}_{6} \mathrm{~F}_{5}\right)_{3}$ jelenlétében

A $\mathrm{Pt}\left(\mathrm{PH}_{3}\right)_{2} \mathrm{Me}_{2}$ komplex esetében a metil-ligandum elvonásának mechanizmusát kvantumkémiai számításokkal is vizsgáltuk (13. Ábra). Megállapítottuk, hogy a metilligandum disszociációjának aktiválási szabadentalpiája lényegesen kisebb $\left[\mathrm{B}\left(\mathrm{C}_{6} \mathrm{~F}_{5}\right)_{3}\left(\mathrm{CH}_{3}\right)\right]^{-}$esetében, mint $\left[\mathrm{BF}_{3}\left(\mathrm{CH}_{3}\right)\right]^{-}$keletkezése során. ${ }^{14}$
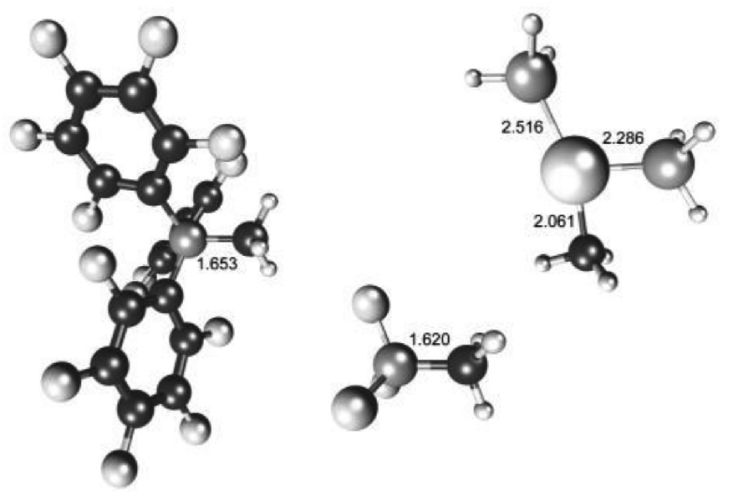

13. Ábra. $\mathrm{A}\left[\mathrm{B}\left(\mathrm{C}_{6} \mathrm{~F}_{5}\right)_{3}\left(\mathrm{CH}_{3}\right)\right]^{-}$, a $\left[\mathrm{BF}_{3}\left(\mathrm{CH}_{3}\right)\right]^{-}$, valamint a $\left[\mathrm{PtMe}\left(\mathrm{PH}_{3}\right)_{2}\right]^{+}$ kation számított szerkezete (BP86/LANL2DZ)
A reakció mechanizmusa a szénvegyületek kémiájából jól ismert SN2 mechanizmusra emlékeztet: a Pt-metil kötés gyengülését (megnyúlását) a B-metil kötés kialakulása (erősödése) kíséri (14. Ábra).

A metil-absztrakciós lépés átmeneti állapotának vizsgálata során kiderült, hogy a Pt-C-B elrendeződés BARF alkalmazása esetén közel lineáris (bal oldali ábra), bórtrifluorid esetében (jobb oldali ábra) a három atom 154.-os szöget zár be.

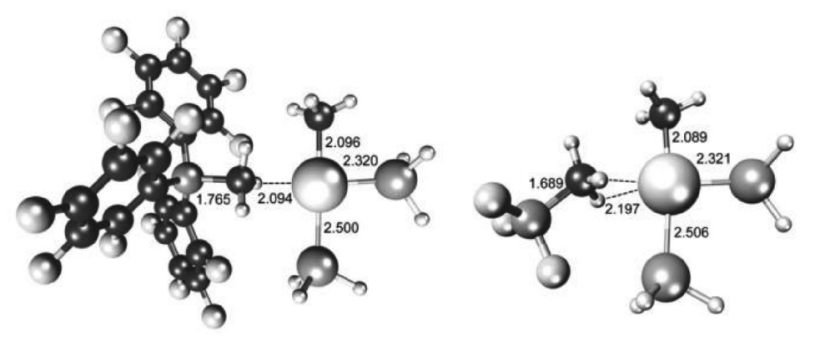

14. Ábra. A $\left[\mathrm{PtMe}_{2}\left(\mathrm{PH}_{3}\right)_{2}\right]$ komplex reakciója $\mathrm{B}\left(\mathrm{C}_{6} \mathrm{~F}_{5}\right)_{3}$, illetve $\mathrm{BF}_{3}$ reagenssel (átmeneti állapotok számított geometriái; BP86/LANL2DZ)

A platina(II) katalizátor-prekurzorok karbonilezési (kitüntetetten hidroformilezési) reakciókban történő alkalmazásának ismeretében nem meglepő a palládiumkomplexek karbonilező aktivitása. A következőkben jórészt az aril-jodidok és alkenil-jodidok aminokarbonilezési reakcióval foglalkozom. Jól ismert a szintetikus analógokak tekinthető aril-triflátok és enol-triflátok mint szubsztrátumok aminokarbonilezési reakciókban történő alkalmazása. A jódszármazékok alkalmazása mellett a 'tiszta' szintetikus reakciók, a termékek könnyebb izolálása, a fluormentes reagensek előnyben részesítése szól.)

Jódaromások, így 2-jód-anilin különböző aminokkal végzett aminokarbonilezése során általában két termék képződése figyelhető meg: a két szén-monoxid beékelődésével nyerhető 2-ketoamid és az egy szén-monoxid beékelődésével keletkező $\operatorname{amid}^{15}$ (15. Ábra).

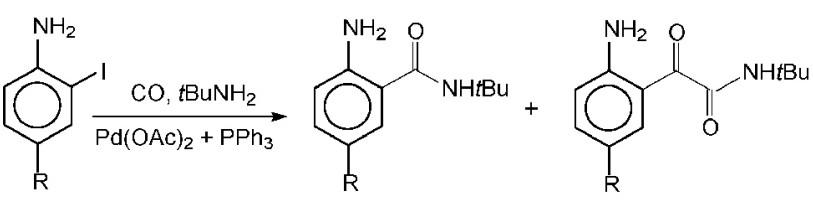

15. Ábra 2-Jód-anilin-származékok aminokarbonilezése

Amennyiben nem alkalmazunk primer vagy szekunder aminokat N-nukleofilként, a bifunkciós szubsztrátum amino-csoportja maga is betöltheti ezt a szerepet. A termékek szerkezete erősen függ az amino-csoporthoz képest para-helyzetben található szubsztituenstől. Elektronküldő szubsztituenseket tartalmazó 1-jód-anilinekkel (és az alapvegyülettel) 2-aril-benz[d][1,3]oxazin-4-on, elektronszívó szubsztituenseket tartalmazó származékokkal intermolekuláris kettős cikloaminokarbonilezési reakcióban dibenzo[b,f][1,5]diazocindion ('diantranilid') típusú termékek keletkeznek (16. Ábra). 


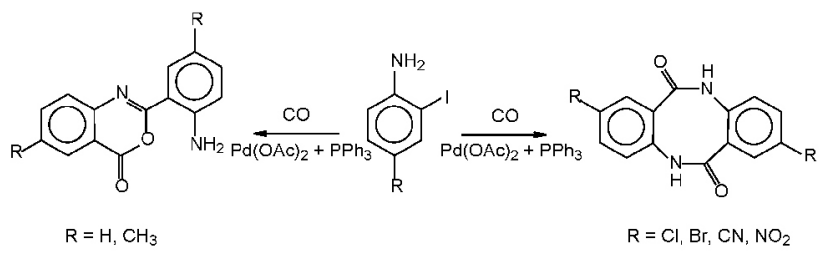

16. Ábra 2-Jódanilin-származékok mint bifunkciós szubsztrátumok aminokarbonilezési reakciói

1,8-Dijód-naftalin szubsztrátummal szekunder aminokkal atmoszférikus szén-monoxid nyomáson végzett reakcióban a várt 1,8-dikarbonsavamidokat kapjuk (17. Ábra). A szén-monoxid nyomás növelésével (40 bar CO) megnő a kettős szén-monoxid beékelődéssel keletkező ketoamidok mennyisége (22-37\%). Primer aminok jelenlétében kizárólag az 1,8-dikarbonsav imid-származékai keletkeznek és jó hozammal izolálhatók ${ }^{16}$ (18. Ábra).

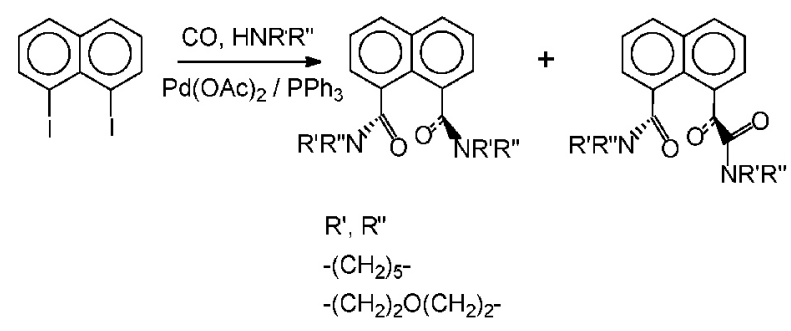

17. Ábra. 1,8-Dijód-naftalin aminokarbonilezése szekunder aminokkal

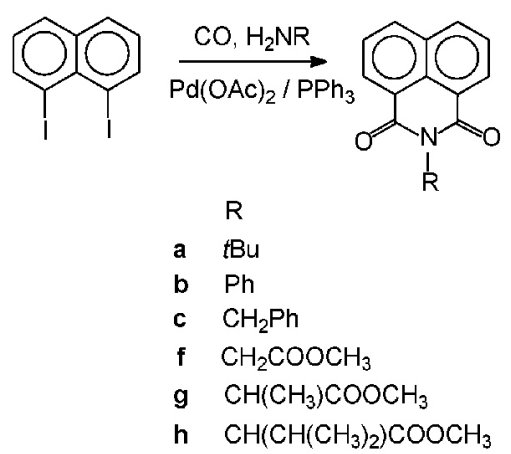

18. Ábra. 1,8-Dijód-naftalin aminokarbonilezése primer aminokkal

A jódpiridinek funkcionalizálása számos gyakorlati fontosságú termék keletkezéséhez vezet. 3-Jód-piridin szubsztrátummal már atmoszférikus nyomáson is megjelenik a nikotinsavamid származékok mellett a 2-ketoamid típusú termék, mely a szén-monoxid nyomás növelésével (40 bar) $90 \%$ feletti kemoszelektivitással keletkezik. ${ }^{17}$

Meglepő módon, az aminokarbonilezési reakciót - azonos reakciókörülmények között - 2-jód-piridinnel végezve csupán nyomokban (GC-MS módszerrel kimutatható, de nem izolálható mennyiségben) keletkezik a ketoamid. Ennek mennyisége a szén-monoxid nyomás növelésével sem változik lényegesen (19. Ábra).

$$
\begin{aligned}
\mathrm{CO}, \mathrm{HNR}^{\prime \prime} \\
\underset{\mathrm{Pd}(\mathrm{OA})_{2} / \mathrm{PPh}_{3}}{\mathrm{Pd}(\mathrm{OAc})_{2} / \mathrm{PPh}_{3}}
\end{aligned}
$$

19. Ábra. 2- és 3-jód-piridin aminokarbonilezése

Az utóbbi szubsztrátumhoz hasonló viselkedés figyelhető meg jód-pirazinnal (20. Ábra). A szerkezet-reaktivitás összefüggések elemzésével megállapítható, hogy a jódaril funkciós csoporthoz képest orto-pozícióban található nitrogén gátolja a második szén-monoxid beépülését.

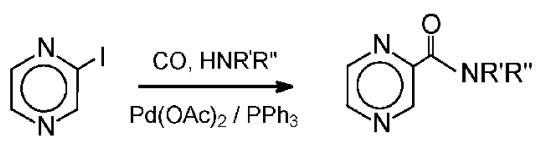

20. Ábra Jód-pirazin aminokarbonilezése

3-Amino-4-jód-piridin különböző primer aminokkal (pl. az ábrán látható terc-butilaminnal) a várt amid és ketoamid termékek mellett nem a szerkezeti analóg 2-jód-anilinnel nyert termékek (pl. diantranilid típusú vegyületek), hanem egy két piridin-egységet tartalmazó vegyes diamidot nyertünk (21. Ábra). Utóbbi termék esetében a szubsztrátum jódaromás funkciós csoportja a terc-butilaminnal, aminocsoportja egy másik szubsztrátum jódaromás csoportjával lép reakcióba. ${ }^{18}$

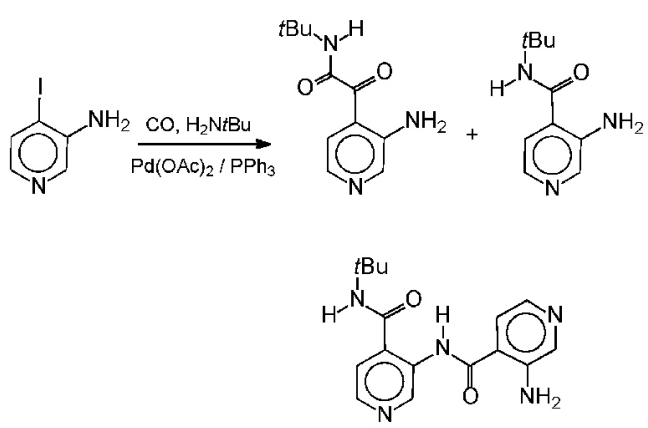

21. Ábra. 3-Amino-4-jód-piridin aminokarbonilezése

A fenti három termék képződése a 22. Ábrán látható katalitikus ciklusokkal magyarázható, melynek ciklus-elemei a korábban említett szubsztrátumokkal is felírhatók. A jódaromás szubsztrátum palládium(0) komplexre történő oxidatív addíciós reakcióban aril-jodo-palládium(II) komplexet ad, mely 
szén-monoxid terminális ligandumként történő megkötése után - a szén-monoxid beékelődésével - acil-jodo-palládium(II) komplexet eredményez. Az amin koordinációját trietilamin jelenlétében HI elvonás követi.

Az ily módon keletkező acil-amido komplexből reduktív eliminációval nyerjük a karbonsavamidot (A ciklus).

Az acil-amido-palládium(II) komplex kulcsfontosságú, hiszen további ('második') szén-monoxid aktiválásával és annak Pd-N kötésbe történő beékelődésével acil-karbamoil komplexhez jutunk. A 2-ketoamid típusú termék ebből reduktív eliminációval keletkezik (B ciklus).

A 3-amino-4-karbonsavamid (az A ciklus terméke) N-nukleofilként is viselkedhet, amely egy második 3-amino-4-jód-piridinből - oxidatív addíció, szén-monoxid koordináció és beékelődés révén - keletkező acil-komplexszel reagálva adja a 'vegyes' ( $N$-terc-butil-amid és $N$-piridil-amid funkciós csoportot tartalmazó) diamidot (C ciklus)

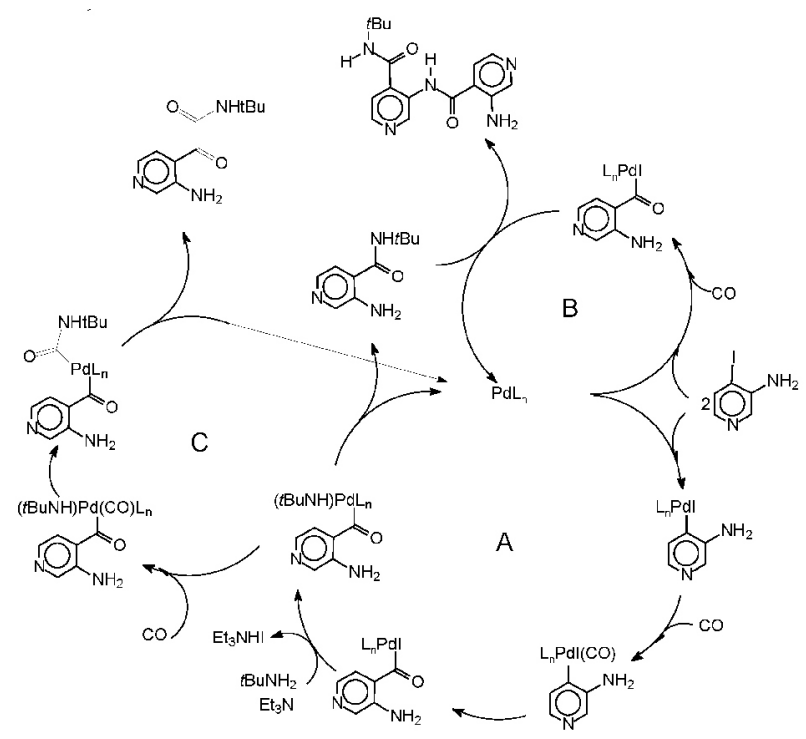

22. Ábra. A 3-amino-4-jód-piridin aminokarbonilezése során megfigyelhető termékek keletkezésének magyarázata egyszerüsített katalitikus ciklusok segítségével

Általában elmondható, hogy a jódaromások és jódalkének aminokarbonilezési reakciója alapvetően abban különbözik, hogy míg előbbi esetben mindig számolni kell mindkét karbonilezett termék (amid, ketoamid) keletkezésével, a jódalkének aminokarbonilezése kizárólag $\alpha, \beta$-telítetlen karbonsavamidokat eredményez. Ez figyelhető meg -aminobenzilfoszfonát mint primer $\operatorname{amin}^{19}$ (23. Ábra) és N.O-dimetil-hidroxilamin ${ }^{20}$ (24. Ábra) alkalmazása esetén is. Ily módon az egyszerüen előállítható jódalkénekből jó hozamú, egylépéses reakcióban gyakorlati fontosságú amid-foszfonátok, illetve széleskörü alkalmazással bíró szintetikus építőelemek (Weinreb-amidok) nyerhetők.

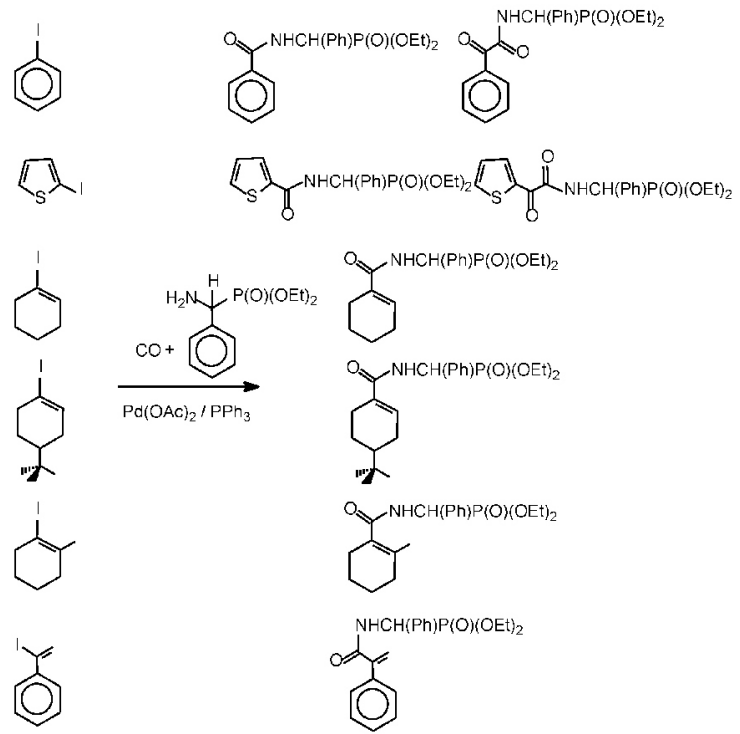

23. Ábra. Jódaromások és jódalkének aminokarbonilezése dietil- $\alpha$-aminobenzilfoszfonát mint $\mathrm{N}$-nukleofil jelenlétében

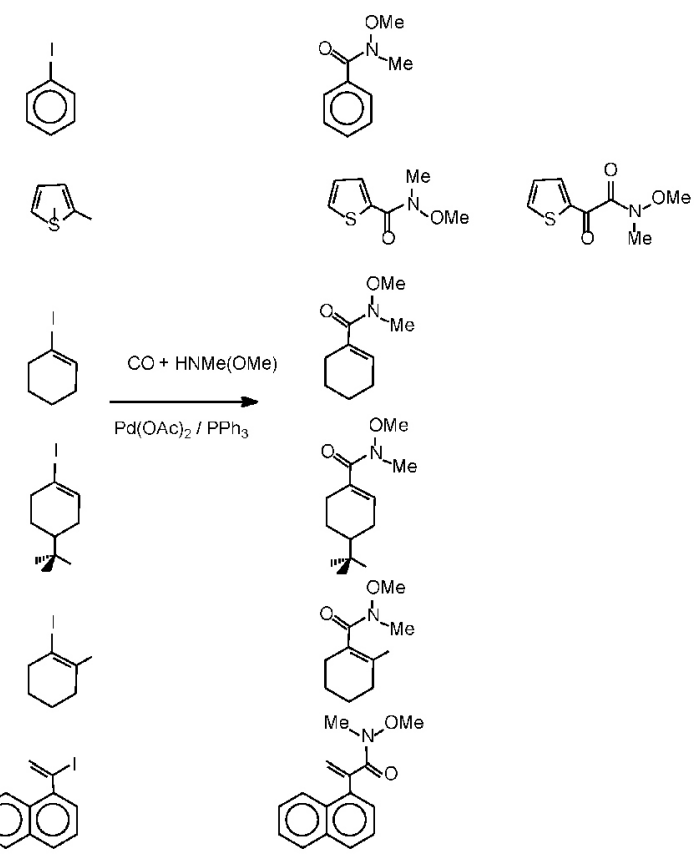

24. Ábra. Jódaromások és jódalkének aminokarbonilezése $N, O$-dimetilhidroxilamin mint N-nukleofil jelenlétében

Az aminokarbonilezési reakció a páratlan szénatomszámú karbonsavszármazékok könnyü elérhetőségét is biztosítja. A páros szénatomszámú, természetben nagyobb mennyiségben megtalálható aldehidekből (pl. dodekanalból) előállítható a transz-jódalkén származék, melynek aminokarbonilezésével nyerhető a 'lánchosszabbított' amid ${ }^{21}$ (25. Ábra). A termékelegyben nyomokban - feltehetően az alkenil-palládium komplex dehidrogénezése révén - amido-csoportot tartalmazó alkin is kimutatható. 


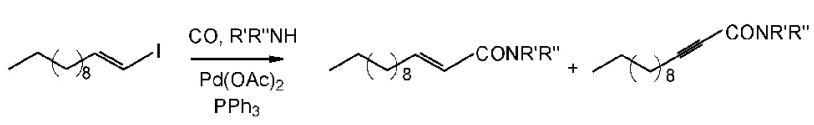

$$
\begin{aligned}
& \begin{array}{ccc} 
& \mathrm{R}^{\prime} & \mathrm{R}^{\prime \prime} \\
\text { a } & \mathrm{H} & \mathrm{tBu} \\
\text { b } & -\left(\mathrm{CH}_{2}\right)_{5-}^{-} \\
\text {c } & -\left(\mathrm{CH}_{2}\right)_{2} \mathrm{O}\left(\mathrm{CH}_{2}\right)_{-}^{-} \\
\text {d } & \mathrm{H} & \mathrm{CH}_{2} \mathrm{COOCH}_{3}
\end{array}
\end{aligned}
$$

25. Ábra. 1-Jód-dodec-1-én aminokarbonilezése

Gyakorlati fontosságú szintetikus építőelemek előállítását teszi lehetővé a fenti reakciókban is alkalmazott keton-hidrazonjódalkén-amid reakciósor. Az acetofenonból, illetve 1,4-diacetilbenzolból elóállított 1-jód-vinil csoporto(ka)t tartalmazó szubsztrátumok kitünő kemoszelektivitású aminokarbonilezése aril-akrilamid típusú termékekhez vezet ${ }^{22,23}$ (26. Ábra).

$$
\text { }
$$

26. Ábra. $\alpha$-Jódsztirol és 1,4-bisz(1'-jód-etenil)-benzol aminokarbonilezése

$\mathrm{Az}$ intramolekuláris aminokarbonilezési reakciók egyik kiváló modell-szubsztrátuma a 2-jód-benzilbromid. Primer aminokkal 'in situ' benzilezési reakció játszódik le, majd az így kapott szekunder amin mint N-nukleofil reagál a jódaromás funkciós csoportból keletkező palládium-acil intermedierrel laktám-képzési reakcióban (27. Ábra). Szekunder aminokkal 2-dialkilaminometil-benzamidokat kapunk, ugyanis a szekunder amin benzilezése tercier amint eredményez, mely N-nukleofilként gyürüzárási reakcióra nem képes. A jódaromás funkciós csoport szekunder aminnal végzett karbonilezési reakciója a várt tercier amid funkciós csoportot eredményezi. ${ }^{24}$

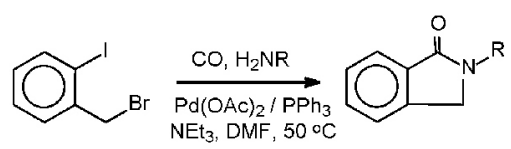

$\mathrm{R}=t \mathrm{Bu}, \mathrm{Ph}, \mathrm{CH}_{2} \mathrm{COOCH}_{3}, \mathrm{CH}\left(\mathrm{CH}_{3}\right) \mathrm{COOCH}_{3}, \mathrm{CH}\left(\mathrm{CH}\left(\mathrm{CH}_{3}\right)_{2}\right) \mathrm{COOCH}_{3}$

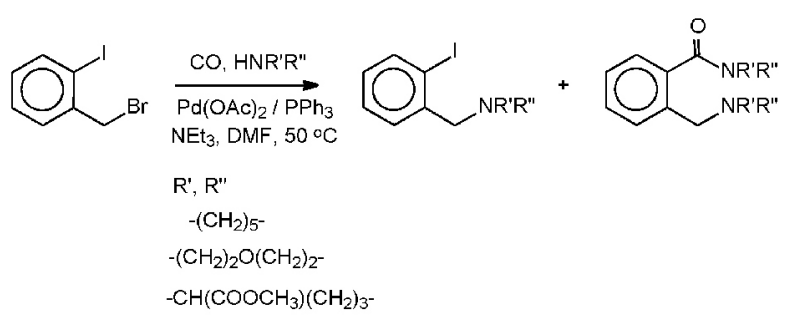

27. Ábra. 2-Jód-benzilamin aminokarbonilezése
Gyakorlati fontosságú amidok elöállítása is egyszerüen megvalósítható a fenti szintetikus stratégiával. A kámforból (28. Ábra), kinuklidinonból ${ }^{25}$ (29. Ábra) vagy tropinonból ${ }^{26}$ (30. Ábra) kialakított jódalkén szubsztrátumok aminokarbonilezésével kitünő hozammal nyerhetők a megfelelő karbonsavamidok. (Említést érdemel, hogy a kámforból kiinduló szintézis során a jódbornén mellett a hídföszénatomon jódot tartalmazó jódkámfén is keletkezik, amely nem vihető homogénkatalitikus aminokarbonilezési reakcióba.)
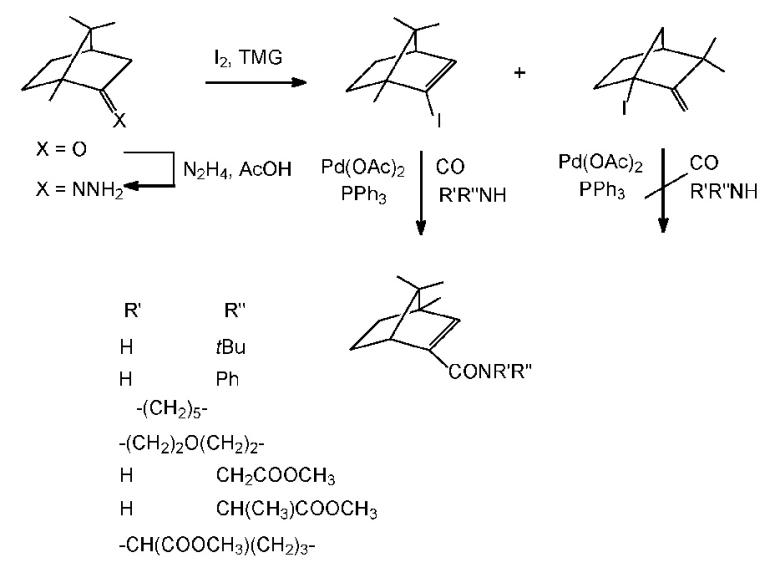

28. Ábra. 2-Jód-bornén aminokarbonilezése.

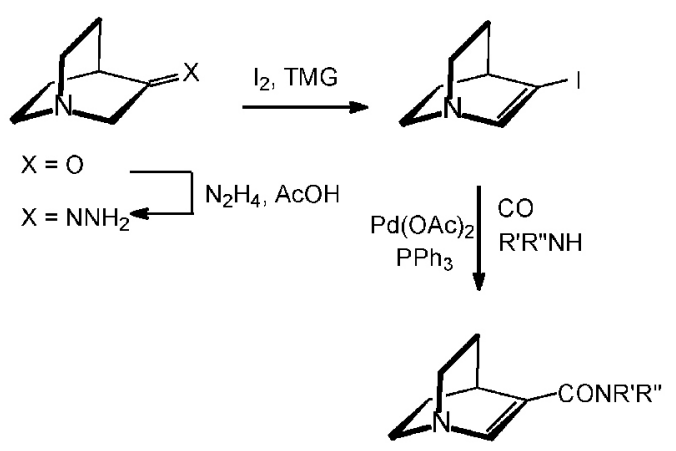

29. Ábra. 2-Jód-kinuklidén aminokarbonilezése (az aminok megegyeznek a 28. Ábrán feltüntetettekkel)

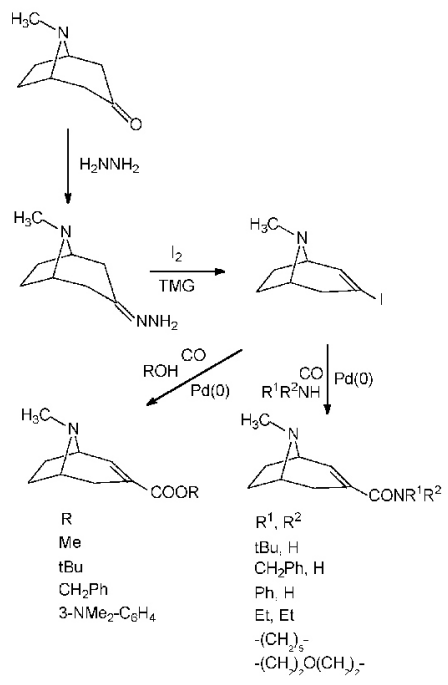

30. Ábra. 3-Jód-2-tropén aminokarbonilezése. 
A ketoszteroidokból kialakított jódalkének funkcionalizálási reakciói a Richter Gedeon Vegyészeti Gyár Rt., valamint az SZTE TTK Szerves Kémiai Tanszékének kutatóival folytatott együttmüködésünk alapját képezik. A hihetetlenül változatos, különböző intermediereket eredményező reakciók (Stille-, karbonilatív Stille- Heck-, foszfonálási, formilezési, hidrazino-karbonilezési, aminokarbonilezési, alkoxi-karbonilezési reakciók) (31. Ábra) közül a következő néhány ábrán csupán a karbonilezési reakciókkal nyerhető származékokból adok ízelítőt. ${ }^{27}$

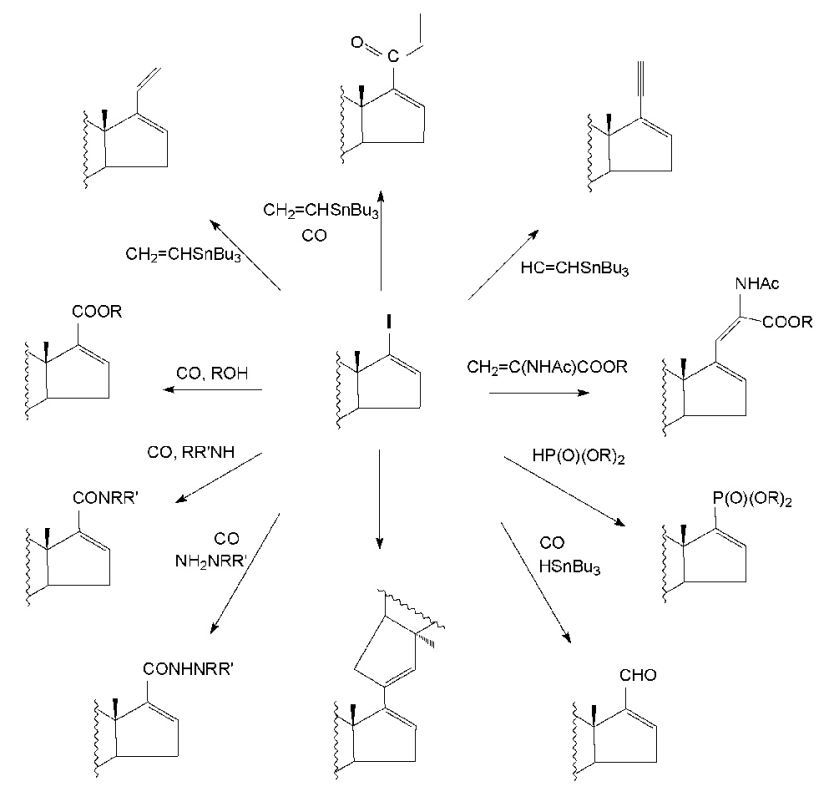

31. Ábra. Szteránvázas jódalkének homogénkatalitikus átalakítása

$O$-Metil- és $O$-benzil-hidroxilaminnal mint $N$-nukleofilekkel hidroxamátok állíthatók elő kiváló hozammal. ${ }^{28}$ (32. Ábra).
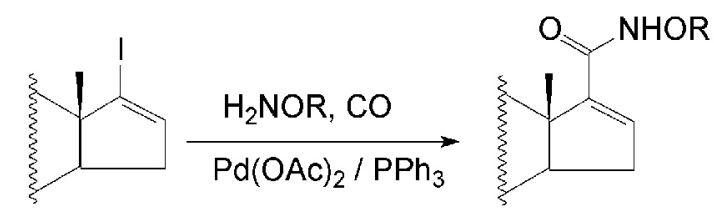

$\mathrm{R}=\mathrm{Me}, \mathrm{Bn}$

32. Ábra. Szteránvázas jódalkének karbonilezési reakciói hidroxilamin származékokkal.

A hidrazinokarbonilezési reakciókban látványos szelektivitást eredményez a hidrazin nitrogénatomjainak különböző bázicitása: míg fenilhidrazin esetében a palládium(szteránvázas)acil komplex a $\beta$-nitrogénen, addig metilhidrazin esetében az .-nitrogénen acilez. $N, N$-difenil-hidrazinnal és $N, N$-dimetil-hidrazinnal a várakozásnak megfelelően a $\beta$-nitrogénen acilezett származék keletkezett ${ }^{29}$ (33. Ábra).

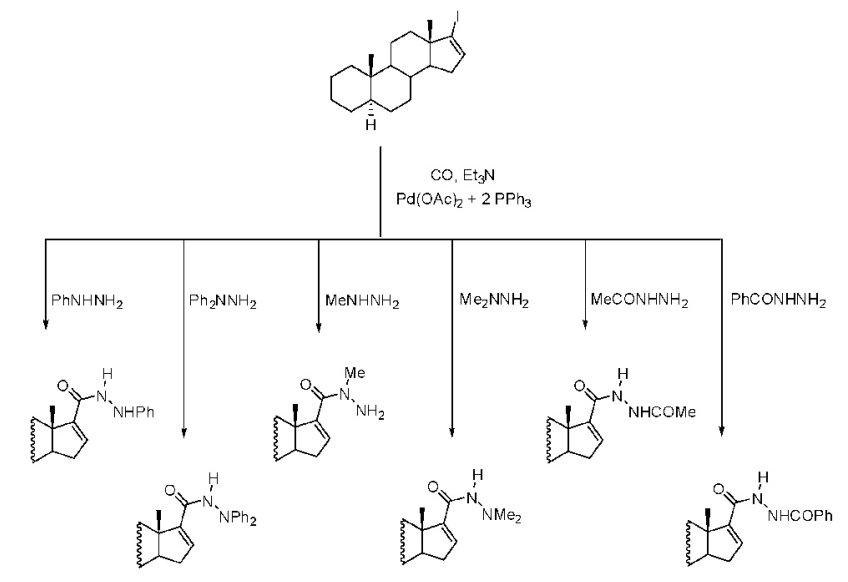

33. Ábra. Szteránvázas jódalkének karbonilezési reakciói hidrazinok jelenlétében.

Szteroidokkal végzett kutatásaink egyik gyakorlati szempontból is fontos része az $5 \alpha$-reduktáz inhibitorok szintézisének több konvencionális reakciót kiváltó, nagyhatékonyságú szintézise. A Finasterid ${ }^{30}$ (34. Ábra) analóg származékainak szintézise során megfigyelhető, hogy olyan aminokkal is végrehajtható a reakció, amelyek hagyományos acilező ágensekkel nem oldhatók meg.

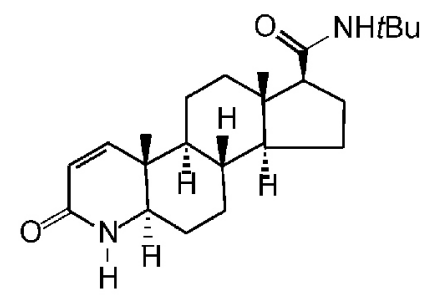

34. Ábra. A szteránvázas 17-karbonsavamidok egyik farmakológiai fontosságú vegyülete, a Finasterid

A 17-ketoszteroidokból kialakított 17-jód-16-én csoport karbonsavamidokká alakítása jó hozamú reakcióban hajtható végre akkor is, ha a 13-as szénatomon található anguláris metil-csoport 'nem-természetes', .-térállású. Számos primer és szekunder amin jelenlétében oldottuk meg mind $3 \beta$-acetoxi-13 $\alpha$-androszta-5-én ${ }^{31}$ (35. Ábra), mind 3-metoxi-13 $\alpha$-estra-1,3,5(10)-trién ${ }^{32}$ (36. Ábra) alapváz funkcionalizálását.

A palládium-katalizált aminokarbonilezés amid-szintézisben megfigyelt hatékonysága akkor mutatkozik meg a leglátványosabban, amikor a szteránváz olyan sztérikusan gátolt pozíciójában szeretnénk karbonilezési reakciót végrehajtani, ahol a konvencionális reakciók hatástalanok. A szteránváz 11-es és 12-es pozíciója tipikusan ilyen. A spirosztán alapvázon (hekogeninből) kialakított 12-jód-11-én funkciós csoport mind alkoxikarbonilezési, mind aminokarbonilezési reakcióban egyetlen terméket ad; az észtereket közepes, az amidokat kitünő hozammal ${ }^{33}$ (37. Ábra). 


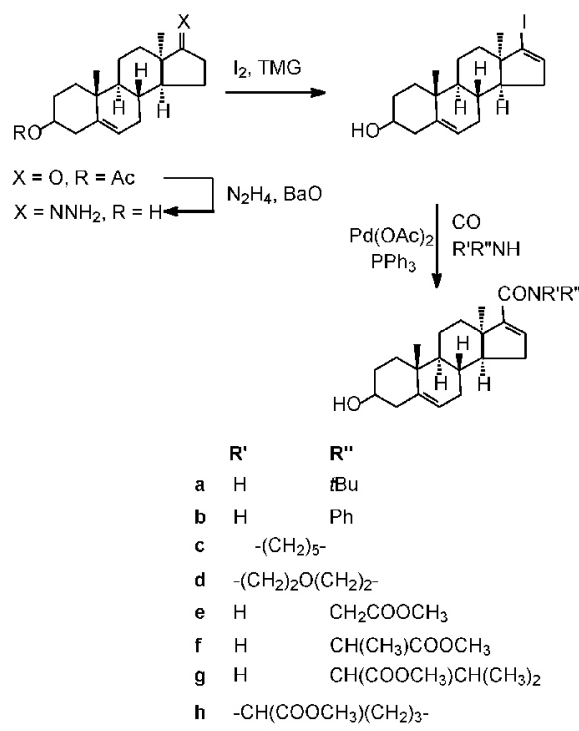

35. Ábra. 'Nem-természetes' androsztánvázas amidok szintézise aminokarbonilezési reakció mint kulcsreakció felhasználásával

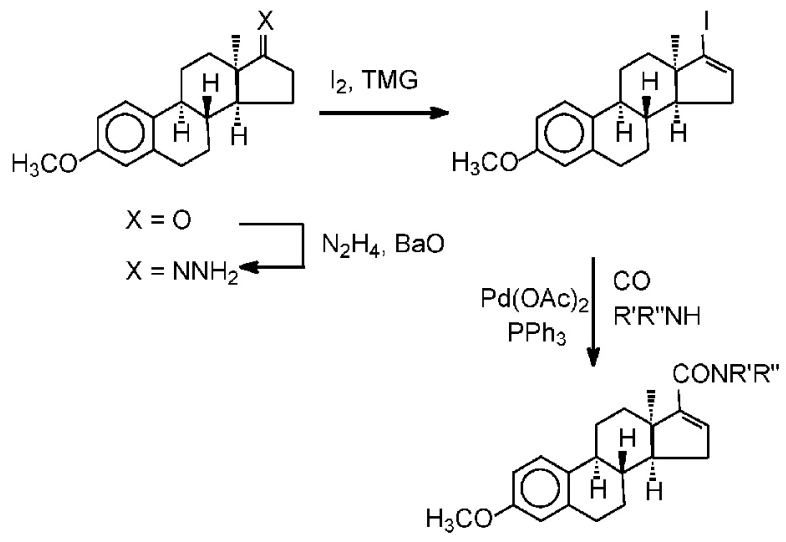

36. Ábra. 'Nem-természetes' ösztránvázas amidok szintézise aminokarbonilezési reakció mint kulcsreakció felhasználásával

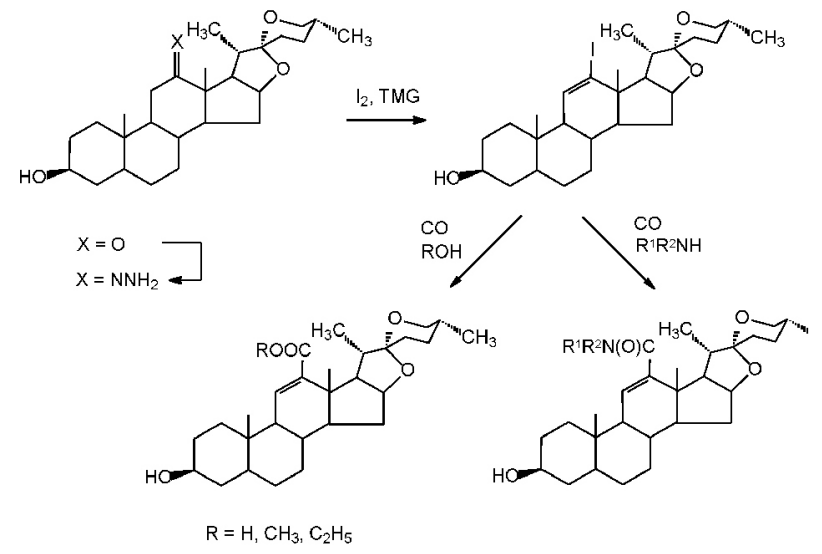

37. Ábra Spirosztán alapvázas vegyületek funkcionalizálása.

A 11-karbonsavamidok szintézisét modellvegyületekkel is megvalósítottuk. Androszt-4-én-3,11,17-trion (adrenoszteron) 3- és 17-keto-csoportját (itt nem részletezett) standard reakciókkal redukáltuk, majd a 11-on csoportból kialakított 11-jód-11-én aminokarbonilezésével a megfelelő karbonsavamidot nyertük $^{34,35}$ (38. Ábra). A 11-karbonsavamidok kiépítését a 3-keto és a 17-keto csoportok védése után is megvalósítottuk a 11-keto-csoportból kialakított 11-jód-11-én aminokarbonilezésével ${ }^{36}$ (39. Ábra).

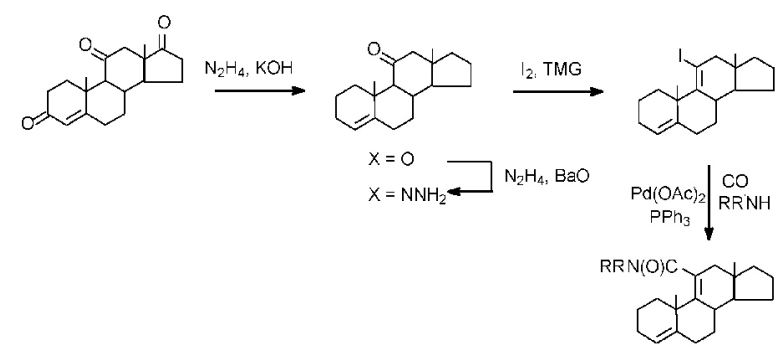

38. Ábra. 11-Karbonsavamidok szelektív szintézise adrenoszteron alapvegyületből kiindulva I.

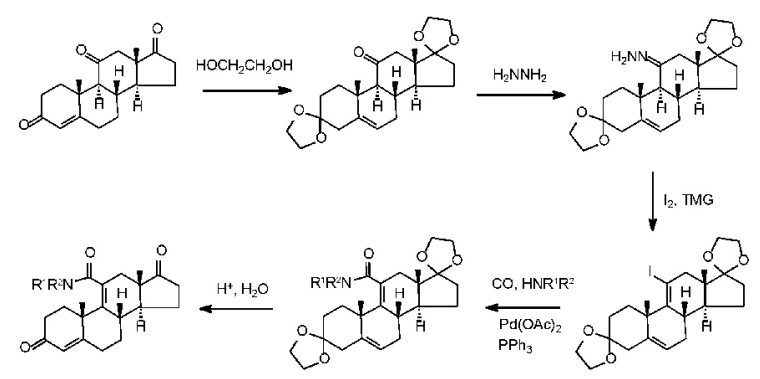

39. Ábra. 11-Karbonsavamidok szelektív szintézise adrenoszteron alapvegyületből kiindulva II.

Az aminokarbonilezési reakció egyszerüsített mechanizmusát az utóbbi jódalkén funkciós csoport aminokarbonilezésének segítségével mutatjuk be (40. Ábra). A jódalkén oxidatív addícióját a szén-monoxid koordinációja és palládium-alkenil kötésbe történö beékelődése követi. A palládium(II)acil-komplex a reakció egyik kulcsintermedierje: a koordinációs kémiában kevésbé járatosak bátran tekinthetnek erre a komplexre mint egy - karbonsav-kloridnál nagyságrendekkel nagyobb aktivitású - acilező ágensre. Az amin koordinációját, a HI eliminációval keletkező amid-acil-palládium(II) komplex kialakulását az amid reduktív eliminációja követi a nagy reaktivitású, koordinatíve telítetlen palládium(0) komplex keletkezése közben.

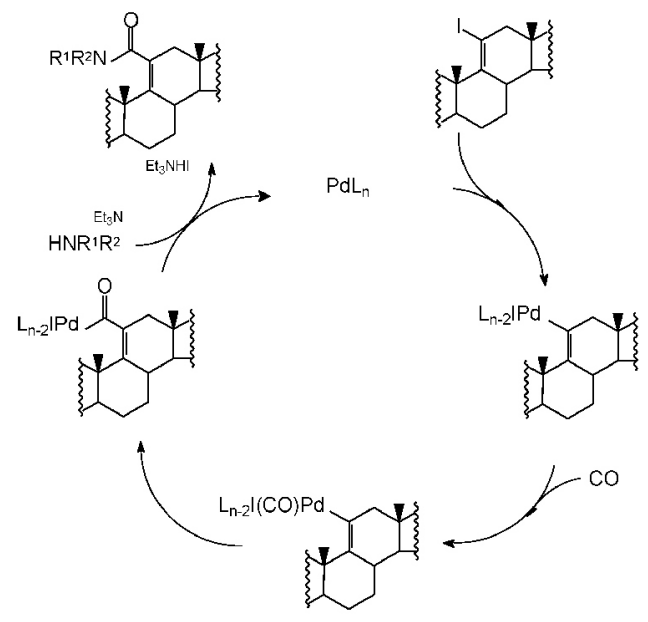

40. Ábra. 11-Karbonsavmidok keletkezését leíró egyszerüsített katalitikus ciklus 
Első ízben vizsgáltuk jódalkének diasztereoszelektív aminokarbonilezését. Enantiomer-tiszta jódalkénként 17-jód-androszt-16-ént ('ANDJÓD'-ot), aminként az axiális kiralitáselemet tartalmazó 2,2'-diamino-1,1'-binaftil ('BINAM') enantiomerjeit, illetve racém elegyét használtuk $^{37}$ (41. Ábra). Az $\left(R_{a x}\right)$-BINAM-mal és $\left(S_{a x}\right)$-BINAM-mal preparált amid-epimerek birtokában részletes NMR vizsgálatokkal meghatároztuk a racém BINAM-mal kapott elegyek diasztereomer-összetételét. Bár jódalkén esetében kettős szén-monoxid beékelödéssel (2-ketokarbonsav-keletkezésével) nem kellett számolnunk, a monoamid mellett a dikarbonsavamid képződése bonyolította az értékelést.

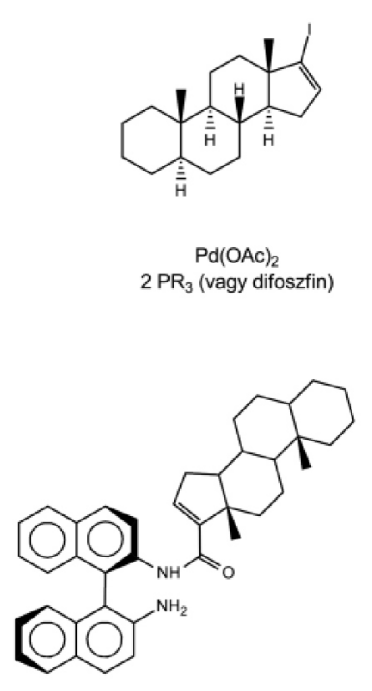

$+$

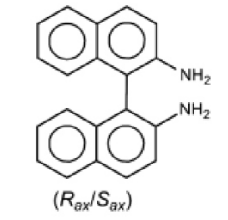

$\left(R_{\mathrm{ax}}\right)$
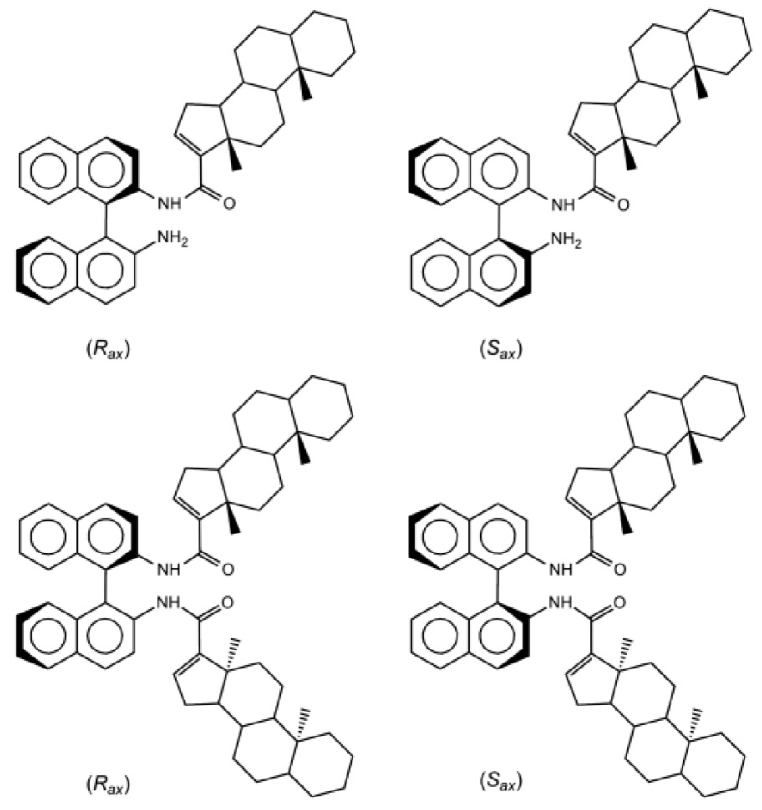

$\left(S_{\mathrm{ax}}\right)$

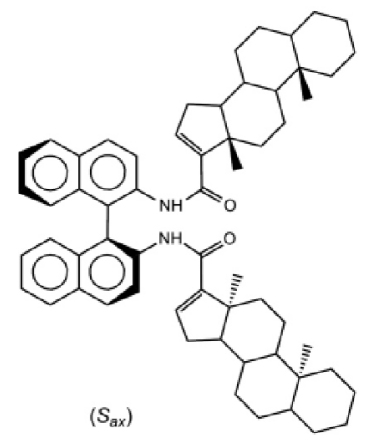

41. Ábra. ANDJÓD diasztereoszelektív aminokarbonilezése BINAM mint $N$-nukleofil felhasználásával

A fenti reakciósort megismételtük olyan jódalkénnel, amelynek mindkét enantiomerjét egyszerüen elő tudtuk állítani. A kámforból kiinduló jódalkén-szintézis során nagy tisztaságban nyertük a két enantiomerikusan tiszta jódalként, amelyek BINAM-mal végzett aszimmetrikus aminokarbonilezése monoamidok és diamidok disztereomer elegyét eredményezte ${ }^{38}$ (42. Ábra). Különböző akirális $\left(\mathrm{PPh}_{3}, 1,3\right.$-bisz(difenilfoszfino)propán) és királis (DIOP, BDPP, BINAP) ligandumokkal végzett kísérletek során viszonylag kismértékü (10\% körüli) diasztereoszelektivitás értékeket kaptunk.

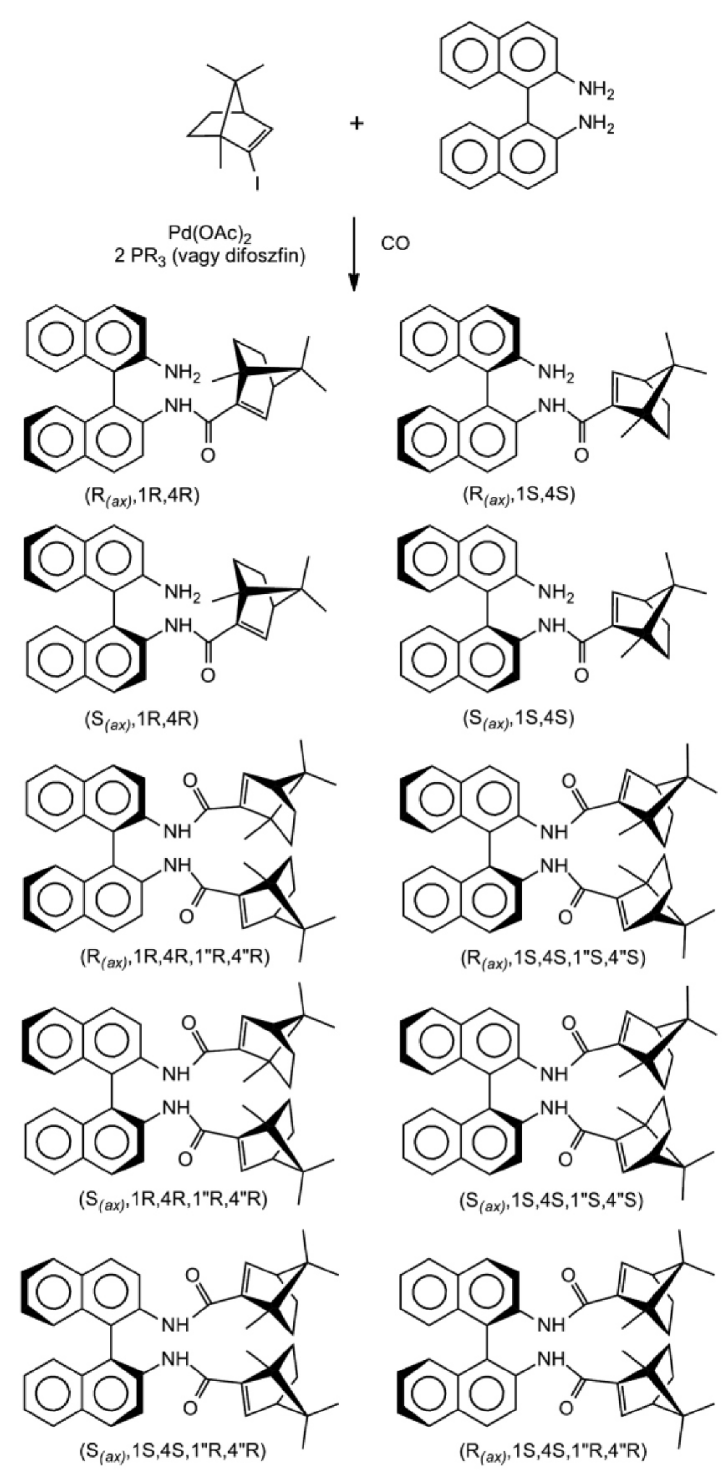

42. Ábra. 2-Jód-bornén diasztereoszelektív aminokarbonilezése BINAM mint $N$-nukleofil felhasználásával

A korábbiakhoz hasonlóan folytattuk azokat a vizsgálatainkat, amelyek bonyolultabb struktúrák nagyhatékonyságú szintézisét tüzték ki célul. 2-Metil-rezorcin alapú kavitandok felső peremének funkcionalizálása során elsősorban nagy szelektivitást és aktivitást biztosító homogénkatalitius reakciókra támaszkodtunk.

Tekintettel az idő rövidségére, az előadás szakmai részének zárásaként csupán egy tetrakisz(2-ketoamid)-kavitand származék szintézisének legérdekesebb részletére szeretnék rámutatni. A kavitand 'alap-kosár' kialakítása acetaldehid és 2-metil-rezorcin kondenzációs reakciójában, majd ezt követően klór-bróm-metán alkalmazásával, a felső perem dioximetilén-hidas zárásával történt. A nagy üreggel rendelkező kavitand 'emeleteinek' kialakítását (benzilhelyzetű brómozás, 4-jód-fenollal történő éterképzés, palládium-katalizált etinilezés és ezt követő, 4-jód-fenilaziddal történő azid-alkin $(3+2)$ cikloaddíció) nem részletezem. ${ }^{39}$ 
$\mathrm{Az}$ aminokarbonilezési reakció során nyert tetrakisz(2-ketoamid) származék szintézise során szokatlanul nagymértékü kemoszelektivitást tapasztaltunk. Nem jódaromás/amid/ketoamid funkciós csoportok 'statisztikus' elegyét kaptuk termékként, hanem nagy kemoszelektivitással ('tetra-szelektivitással') nyertük a tetrakisz(2-ketoamidot) (vagy más reakciókörülmények között a tetraamidot $)^{40,41}$ (43. Ábra). A reakció részleteinek tisztázása (ön-felismerés, kommunikáció a négy reakciócentrum között) a következő évek munkájának vélhetően egyik legizgalmasabb feladata lesz.

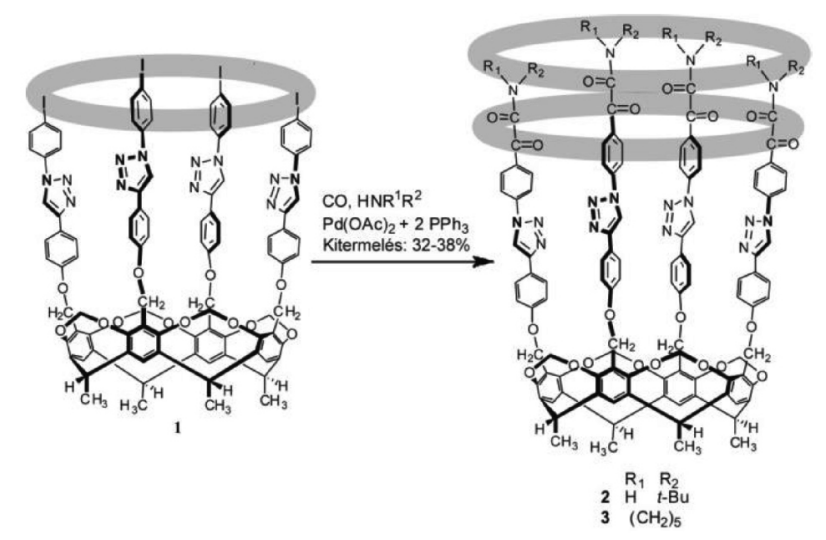

43. Ábra. Nagy szelektivitású aminokarbonilezési reakció 2-metil-rezorcin alapú kavitandokkal

Öszinte hálával tartozom mindazoknak, akik kutatómunkám során támogattak. Elsőként annak a két nagyformátumú, iskolateremtő tudósnak szeretnék köszönetet mondani, akik elkötelezettségükkel, a kutatómunka iránti mérhetetlen alázatukkal példaként szolgálnak generációk számára. Markó László a Veszprémi Vegyipari Egyetem Szerves Kémia Tanszékén (és MTA Petrolkémiai Tanszéki Kutatócsoportjában), Piero Pino a zürichi ETH professzoraként jelentett számomra meghatározó példát.

Heil Bálint kutatócsoportjában, Tőrös Szilárddal kezdtem meg diákkörös kutatásaimat, akik számos munkatársukkal együtt nagy türelemmel segítették munkámat. Mindig nagy örömmel és némi nosztalgiával gondolok a veszprémi és a zürichi kutatócsoportokban eltöltött évekre.

Húsz évvel ezelőtt kerültem Pécsre, ahol lehetőségem nyílt végtelenül szerény alapokról indulva - önálló kutatócsoport felépítésére. Ebben meghatározó szerepe volt a TTK akkori dékánjának, Tóth József professzornak, és két, velem együtt a Kémiai Intézetbe került professzornak, Nagy Gézának és Kilár Ferencnek. Talán ők is egyetértenek velem abban, ha nem sikerült volna ezt a bátor személyi fejlesztést megvalósítani, valószínüleg nem tartanánk itt. Abban viszont egészen bizonyos vagyok, hogy én nem állhatnék akadémiai levelező tagként Önök elött.

Köszönetemet szeretném kifejezni minden kollégámnak, volt és jelenlegi hallgatómnak, PhD hallgatómnak, akikkel a bemutatott (és idő hiányában be nem mutatott) szakmai eredményeket sikerült elérnem. Pécsi kollégáim közül szeretném kiemelni Kégl Tamás, Kunsági-Máté Sándor, Csók Zsolt, Takács Attila, Pongrácz Péter segítségét. Skodáné Földes Rita nevét a korábbi, veszprémi együttmüködőket bemutató ábrán is feltüntettem; talán a leghosszabb ideje vele dolgozom együtt.

Köszönöm Szegedi Tudományegyetem professzorainak, Wölfling Jánosnak, Schneider Gyulának és munkatársaiknak, valamint a Richter Gedeon Vegyészeti Gyár NyRt. vezető kutatóinak, Tuba Zoltánnak, Mahó Sándornak és munkatársaiknak, hogy a szteroidkémia területén sok izgalmas problémával foglalkozhattam. Keglevich György és munkatársai révén számos új foszfor-ligandum koordinációs és katalitikus kémiájával ismerkedhettem meg, amiért őszinte hálával tartozom.

A számos külföldi együttműködő közül Mariette Pereira és Serafino Gladiali segítségét emelném ki, amellyel nagyban hozzájárultak munkám sikeréhez.

Öszinte hálával tartozom középiskolám, a Kaposvári Táncsics Mihály Gimnázium tanárainak, különösképpen matematika-fizika tagozatos osztályunk osztályfőnökének, Gál Józsefnének és kémiatanáromnak, Szántó László tanár úrnak, aki legnagyobb örömömre személyesen jelen van a székfoglalón.

Végezetül köszönöm szüleimnek, testvéreimnek, és szűkebb családomnak, feleségemnek és fiaimnak, hogy munkám minden percében élvezhettem támogatásukat és végtelen türelmüket.

Köszönöm a figyelmet! 


\section{Hivatkozások}

1. Zeise, W. C. Poggendorf's Ann. Phys. Chem. 1831, 97, 497-541.

2. Faigl, F.; Kollár, L.; Kotschy, A.; Szepes, L. Szerves fémvegyületek kémiája. Nemzeti Tankönyvkiadó, Budapest, 2002.

3. Farkas, E.; Kollár, L.; Moret, M.; Sironi, A. Organometallics 1996, 15, 1345-1350. https://doi.org/10.1021/om9509406

4. Jánosi, L.; Kollár, L.; Macchi, P.; Sironi, A. J. Organomet. Chem. 2006, 691, 2846-2852. https://doi.org/10.1016/j.jorganchem.2006.02.026

5. Jánosi, L.; Kollár, L.; Macchi, P.; Sironi, A. Trans. Met. Chem. 2007, 32, 746-752.

https://doi.org/10.1007/s11243-007-0236-0

6. Kollár, L.; Bakos, J.; Tóth, I.; Heil, B. J. Organomet. Chem. 1988, 350, 277-284.

https://doi.org/10.1016/0022-328X(88)80383-8

7. Kollár, L.; Bakos, J.; Tóth, I.; Heil, B. J. Organomet. Chem. 1989, 370, 257-261.

https://doi.org/10.1016/0022-328X(89)87289-4

8. Gladiali, S.; Bayón, J. C.; Claver, C. Tetrahedron: Asymm. 1995, 6, 1453-1474.

https://doi.org/10.1016/0957-4166(95)00178-R

9. Agbossou, F.; Carpentier, J-F.; Mortreux, A. Chem. Rev. 1995, 95, 2485-2506. https://doi.org/10.1021/cr00039a008

10. Tóth, I.; Kégl, T.; Elsevier, C. J.; Kollár, L. Inorg. Chem. 1994, 33, 5708-5712. https://doi.org/10.1021/ic00103a017

11. Pongrácz, P.; Papp, T.; Kollár, L.; Kégl, T. Organometallics 2014, 33, 1389-1396. https://doi.org/10.1021/om401104g

12. Pongrácz, P.; Kollár, L. J. Organomet. Chem. (nyomdában)

13. Casey, C. P.; Martins, S. C.; Fagan, M. A. J. Am. Chem. Soc. 2004, 126, 5585-5592.

https://doi.org/10.1021/ja0318479

14. Jánosi, L.; Kégl, T.; Kollár, L. J. Organomet. Chem. 2008, 693, 1127-1135.

https://doi.org/10.1016/j.jorganchem.2008.01.018

15. Ács, P.; Müller, E.; Rangits, G.; Lóránd, T.; Kollár, L. Tetrahedron 2006, 62, 12051-12056. https://doi.org/10.1016/j.tet.2006.09.076

16. Takács, A.; Ács, P.; Kollár, L. Tetrahedron 2008, 64, 983-987. https://doi.org/10.1016/j.tet.2007.10.026

17. Takács, A.; Jakab, B.; Petz, A.; Kollár, L. Tetrahedron 2007, 63, 10372-10378. https://doi.org/10.1016/j.tet.2007.07.017

18. Szőke, G.; Takács, A.; Berente, Z.; Petz, A.; Kollár, L. Tetrahedron 2016, 72, 3063-3067. https://doi.org/10.1016/j.tet.2016.04.030

19. Takács, A.; Petz, A.; Kollár, L. Tetrahedron 2008, 64, 8726-8730. https://doi.org/10.1016/j.tet.2008.06.096

20. Takács, A.; Petz, A.; Kollár, L. Tetrahedron 2010, 66, 4479-4483. https://doi.org/10.1016/j.tet.2010.04.076

21. Takács, A.; Ács, P.; Farkas, R.; Kokotos, G.; Kollár, L. Tetrahedron 2008, 64, 9874-9878.

https://doi.org/10.1016/j.tet.2008.08.022
22. Szilágyi, A.; Farkas, R.; Petz, A.; Kollár, L. Tetrahedron 2009, 65, 4484-4489. https://doi.org/10.1016/j.tet.2009.04.012

23. Takács, A.; Farkas, R.; Petz, A.; Kollár, L. Tetrahedron 2008, 64, 61-66. https://doi.org/10.1016/j.tet.2007.10.102

24. Marosvölgyi-Haskó, D.; Takács, A.; Riedl, Z.; Kollár, L. Tetrahedron 2011, 67, 1036-1040. https://doi.org/10.1016/j.tet.2010.11.099

25. Horváth, L.; Petz, A.; Kollár, L. Lett. Org. Chem. 2010, 7, 54-60. https://doi.org/10.2174/157017810790534048

26. Horváth, L.; Berente, Z.; Kollár, L. Lett. Org. Chem. 2007, 4, 236-238. https://doi.org/10.2174/157017807781024345

27. Skoda-Földes, R.; Kollár, L. Chem. Rev. 2003, 103, 4095-4129. https://doi.org/10.1021/cr020075g

28. Szarka, Z.; Skoda-Földes, R.; Kollár, L.; Horváth, J.; Tuba, Z. Synth. Commun. 2000, 30, 1945-1953. https://doi.org/10.1080/00397910008087244

29. Skoda-Földes, R.; Szarka, Z.; Kollár, L.; Dinya, Z.; Horváth, J.; Tuba, Z. J. Org. Chem. 1999, 64, 2134-2136. https://doi.org/10.1021/jo9819842

30. Holt, D. A.; Levy, M. A.; Metcalf, B. W.SmithKline Beecham Co.; EP. 0343954 A2, 1989.; Chem. Abstr. 1990; 112, 198890n

31. Ács, P.; Takács, A.; Szilágyi, A.; Wölfling, J.; Schneider, G; Kollár, L. Steroids 2009, 74, 419-423. https://doi.org/10.1016/j.steroids.2008.12.009

32. Ács, P.; Takács, A.; Szilágyi, A.; Wölfling, J.; Schneider, G.; Kollár, L. Steroids 2008, 73, 669-675. https://doi.org/10.1016/j.steroids.2008.02.002

33. Ács, P.; Müller, E.; Czira, G.; Mahó, S.; Pereira, M.; Kollár, L. Steroids 2006, 71, 875-879.

https://doi.org/10.1016/j.steroids.2006.05.019

34. Kiss, M.; Pálinkás, N.; Takács, A.; Mahó, S.; Kollár, L. Steroids 2013, 78, 693-699. https://doi.org/10.1016/j.steroids.2013.02.013

35. Carrilho, R. M. B.; Almeida, A. R.; Kiss, M.; Kollár, L.; Skoda-Földes, R.; Dabrowski, J. M.; Moreno, M. J. S. M.; Pereira, M. M. Eur. J. Org. Chem. 2015, 1840-1847. https://doi.org/10.1002/ejoc.201403444

36. Ács, P.; Takács, A.; Kiss, M.; Pálinkás, N.; Mahó, S.; Kollár, L. Steroids 2011, 76, 280-290. https://doi.org/10.1016/j.steroids.2010.11.008

37. Mikle, G.; Boros, B; Kollár, L. Tetrahedron: Asymm. 2014, 25, 1527-1531. https://doi.org/10.1016/j.tetasy.2014.10.013

38. Mikle, G.; Boros, B.; Kollár, L. Tetrahedron: Asymm. 2016, 27, 377-383. https://doi.org/10.1016/j.tetasy.2016.03.010

39. Csók, Z.; Takátsy, A.; Kollár, L. Tetrahedron 2012, 68, 2657-2661. https://doi.org/10.1016/j.tet.2012.01.065

40. Nagymihály, Z.; Caturelles, N. A. M. S.; Takátsy, A.; Kollár, L.; Albuquerque, R. Q.; Csók, Z. J. Org. Chem. (accepted)

41. Csók, Z.; Szuroczki, P.; Kollár, L.; Ngo, H. M.; Ledoux-Rak, I.; Caturelles, N. A. M. S.; Albuquerque, R. Q. J. Phys. Chem. C. 2015, 119, 12608-12615. https://doi.org/10.1021/acs.jpcc.5b03047 
From model compounds to derivatives of practical importance: wandering on the border of organic and inorganic chemistry (a personal account)

The results of the past two decades achieved by the author and his colleagues are summarised in this review on the occasion of his inauguration as a corresponding member of the Hungarian Academy of Sciences.

Homogeneous catalysis has become an indispensable tool in synthesis. Since the early discovery of the Zeise-salt, potassium-[trichloro-ethylene-platinate(II)], the first transition metal-organic compound, the exploitation of homogeneous catalytic reactions in organic synthesis resulted in a real 'break-through' of the chemistry of the last decades. The deeper understanding of the formation of the transition metal-carbon bond, the recognition of their properties and the mechanistic investigations of the most widely used catalytic reaction (including rationalization of the catalytic cycles) have rendered many of the transition metal-catalysed reactions as a solution of practical syntheses.

The first part of this lecture comprised the results on the coordination chemistry of platinum with special focus on platinum-diphosphane-tin(II) halide systems. Both solution and crystal structures of $[\mathrm{PtX}(\mathrm{SnCl} 3)($ diphosphane $)]$ type complexes $(\mathrm{X}=\mathrm{Cl}, \mathrm{I}$; diphosphane $=2$,4-bis(diphenylphosphano)pentane or similar chiral diphosphanes possessing central or axial element of chirality) were discussed. The unexpected phenomenon, the strong temperature dependence of the optical yields in the hydroformylation of styrene derivatives, was rationalised. The reversal of the favoured absolute configuration was explained by the highly different reactivity of the two diastereomeric transition states, i.e., coordinating the prochiral alkene either from the si or re enantiosites and the reversibility of the platinum-alkyl bond formation.

In the second part of the presentation the application of palladium-catalysed carbonylation reactions was shown with special focus on aminocarbonylation of iodoaromatics and iodoalkenes. Structure-reactivity and structurechemoselectivity relations were shown using several series of iodoaromatics (iodoaniline derivatives, iodoindoles, iodopyridines, etc.) The formation of two types of products obtained in aminocarbonylation of iodoaromatics (carboxamides and 2-ketocarboxamides obtained by single and double carbon monoxide insertion, respectively) were rationalised by providing catalytic cycles. The aminocarbonylation of various iodoalkenes resulted in the exclusive formation of carboxamide.

The exploitation of the above results obtained with model substrates was discussed in the third part of the presentation. Compounds with practical (pharmaceutical) importance were synthesised using homogeneous catalytic reactions (mainly various carbonylations and cross-coupling reactions). The high-yielding synthesis of isoindolinones can be carried out in intramolecular aminocarbonylation reaction using 2-iodobenzylamine derivatives (or their precursor, 2-iodonenzyl bromide) substrates. 3-Carboxamido-2-tropene, 2-carboxamido-2-quinuclidene and 2-carboxamidobornene derivatives were synthesised in palladium-catalysed aminocarbonylation. Simple and functionalised amines (for instance, amino acid esters) were used as N-nucleophiles. The efficiency of these reactions was shown in the functionalisation of steroids. The high reactivity of the palladium-acyl catalytic intermediate enabled the synthesis of otherwise hardly (or non) available products. For instance, facile functionalisations can be carried out at the sterically most hindered C-11 and C-12 positions.

Finally, examples were shown for palladium-catalysed diastereoselective aminocarbonylation using an $\mathrm{N}$-nucleophile with axial chirality (2,2'-diamino-1,1'binaphthatene, both in racemic and enantiomerically pure form) and 17-iodo-16-androstene or 2-iodobornene as substrates. 